\title{
CONUS TULIPA.
}

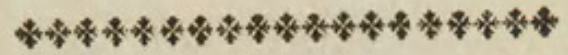

CHARACTER GENERICUS.

Animal Limax.

Testa univalvis, convoluta, turbinata.

Apertura effusa, longitudinalis, linearis, edentula, basi integra.

Columella lævis.

Lin. Syst. Nat. p. 1165.

CHARACTER SPECIFICUS, छC.

CONUS testa ventricosa alba, nebulis longitudinalibus aurantiis, punctis transversis fuscis, apertura dehiscente.

CONUS TULIPA. C. testa oblonga gibba lævi, apertura dehiscente.

Lin. Syst. Nat. p. 1172.

Rumph. mus. t. 34 f. к.

Knorr vergn. 5. t. 20. f. 1.2.

Inter testas pulcherrimas merito numeratur Conus Tulipa cujus magnitudinem veram ostendit tabula. Circa littora Indica precipue conspicitur. 


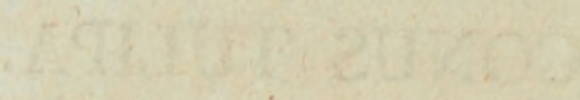

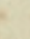

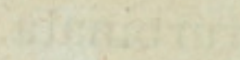

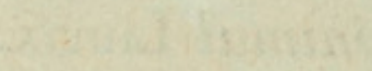

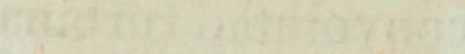




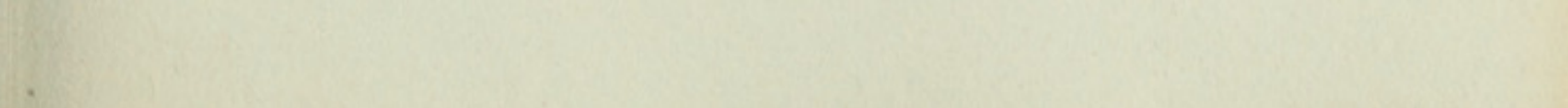



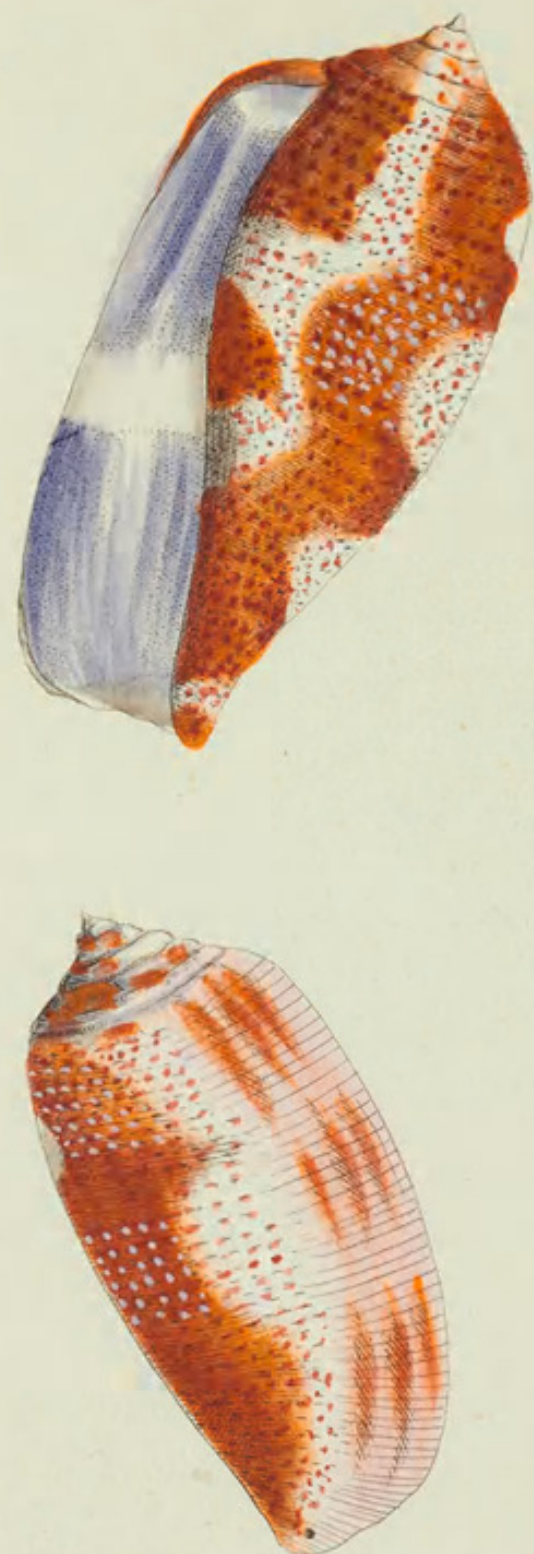


\section{THE}

\section{TULIP CONE.}

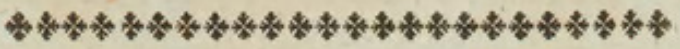

\section{GENERIC CHARACTER.}

Animal resembling a Limax or Slug. Shell more or less conic or pyramidal. Aperture longitudinal, linear, without teeth, entire at the base.

Pillar smooth.

\section{SPECIFIC CHARACTER, EC.}

Smooth white ventricose CONE, with longitudinal orange-coloured clouds, and dusky transverse specks.

The Tulip-Shell or TULIP CONE.

The Tulip Cone is justly considered as one of the most beautiful shells of its tribe: it is a native of the Indian seas, and is represented on the plate in its natural size. 


\section{$2 \mathrm{BHL}$ Biodiversity Heritage Library}

Shaw, George. 1801. "The Tulip Cone, Conus tulipa [PI. 523]." The Naturalist's Miscellany 13(CXLVII), https://doi.org/10.5962/p.310969.

View This Item Online: https://www.biodiversitylibrary.org/item/281546

DOI: https://doi.org/10.5962/p.310969

Permalink: https://www.biodiversitylibrary.org/partpdf/310969

\section{Holding Institution}

Museums Victoria

\section{Sponsored by}

Atlas of Living Australia

\section{Copyright \& Reuse}

Copyright Status: Public domain. The BHL considers that this work is no longer under copyright protection.

This document was created from content at the Biodiversity Heritage Library, the world's largest open access digital library for biodiversity literature and archives. Visit BHL at https://www.biodiversitylibrary.org. 